\title{
SISTEM PAKAR DIAGNOSA KERUSAKAN MESIN SEPEDA MOTOR YAMAHA DI COMPION MOTOR DUMAI
}

\author{
Nazarudin $^{1}$, Ade Saputra ${ }^{2}$, Hayatullah Khumaini ${ }^{3}$ \\ ${ }^{1,2,3}$ Sekolah Tinggi Manajemen Informatika \& Komputer (STMIK) Dumai \\ Jl.Utama Karya Bukit Batrem Dumai, 28811 \\ Email: nazarriau@yahoo.com
}

\begin{abstract}
ABSTRAK
Sistem pakar adalah aplikasi berbasis komputer yang digunakan untuk menyelesaikan masalah sebagaimana yang dipikirkan oleh pakar. Pakar yang dimaksud disini adalah orang yang mempunyai keahlian khusus yang dapat menyelesaikan masalah yang tidak dapat diselesaikan oleh orang awam. Namun masalah yang sering muncul adalah bagaimana cara untuk merepresentasikan pengetahuan di antaranya adalah menerapkan sistem pakar yang telah terkomputerisasi sehingga dapat digunakan dalam mendianogsa kerusakan mesin sepeda motor Yamaha Mio J 110cc di bengkel Chompion motor.sehingga dapat memdahkan kinerja mekanik dalam perbaikan motor. Dengan metode Forward Chaining diharapakan dapat membatu sistem dalam mengambil suatu keputusan dalam mendianogsa kerusakan mesin sepeda motor Yamaha Mio J 110 cc. sehingga dengan adanya aplikasi sistem pakar kerusakan mesin sepeda motor ini dapat dengan mudah meyelesaikan permasalahan dalam medianogsa kerusakan mesin sepeda motor Yamaha Mio J 110 cc.
\end{abstract}

Kata kunci : Sistem Pakar, Kerusakan Mesin, Sepeda Motor, Vusual Basic

\section{PENDAHULUAN}

Sepeda motor adalah kendaraan beroda dua yang digerakan oleh sebuah mesin letak kedua roda sebaris lurus dan pada kecepatan tinggi sepeda motor tetap stabil disebabkan oleh gaya__ giroskopik. Sedangkan pada kecepatan rendah, kesetabilan atau keseimbangan sepeda motor bergantung kepada pengaturan setang oleh pengendara. Penggunaan sepeda motor di Indonesia sangat populer karena harganya yang relatif murah, terjangkau untuk sebagian besar kalangan dan penggunaan bahan bakarnya serta biaya operasionalnya cukup hemat.

Masalah bagi pengendara yang tidak mengetahui jenis kerusakan akan sangat fatal apabila jenis kerusakan tersebut tidak segera ditangani. Pada umumnya beberapa pengendara sepeda motor yang kurang mengerti tentang gangguan atau kerusakan yang terjadi pada sepeda motor,khususnya kerusakan pada mesin. Belum adanya suatu aplikasi sistem pakar diagnosa kerusakan mesin sepeda motor di bengkel champion motor. Seiring dengan perkembangan teknologi informasi saat ini sangat diperlukan diberbagai bidang, diantaranya dalam mengatasi permasalahan diatas yaitu suatu sistem yang dapat digunakan untuk diagnosa kerusakan mesin sepeda motor. dalam menyelesaikan sistem ini dapat digunakan dengan metode, yaitu metode forward chaining yaitu : metode pencarian atau teknik pelacakan ke depan yang dimulai dengan informasi yang ada dan pengabungan rule untuk menghasilkan suatu kesimpulan dan tujuan.

\section{a. Pengertian Sistem}

menurut (Fatta, 2007) Untuk mengawali pembahasan tentang analisis dan perancangan sistem informasi, pemahaman akan sistem terlebih dahulu harus ditekankan. Definisi sistem berkembang sesuai dengan konteks dimana pengertian sistem itu digunakan. Berikut akan diberikan beberapa definisi sistem secara umum :

1. Kumpulan dari bagian-bagian yang bekerja sama untuk mencapai tujuan yang sama. Contoh : Sistem tata surya, sistem pencernaan, sistem transportasi umum, sistem otomatif, sistem komputer dan sistem informasi.

2. Sekumpulan objek-objek yang saling berelasi dan berinteraksi serta hubungan antar objek dilihat sebagai satu kesatuan 
IN F O R M A I I A

Jurnal Informatika, Manajemen dan Komputer, Vol. 9 No. 1, Mei 2017

eISSN : 1979-0694

pISSN : 1979-0694

yang dirancang untuk mencapai satu tujuan.

\section{b. Flowchart}

Menurut Flowchart merupakan bagan yang menjelaskan secara rinci langkah - langkah dari proses program. bagan alir program dibuat dari derivikasi bagan alir sistem.(Jogiyanto, 2008)

\section{c. Context Diagram}

Diagram konteks adalah tingkatan tertinggi dalam diagram aliran data dan hanya memuat satu proses, menunjukkan sistem secara keseluruhan. proses tersebut diberi nomor nol. semua entitas eksternal yang ditunjukkan pada diagram konteks berikut aliran data - aliran data utama menuju dan dari sistem. Diagram tersebut tidak memuat penyimpanan data dan tampak sederhana untuk diciptakan, begitu entitas entitas eksternal serta aliran data - aliran data menuju dan dari sistem diketahui penganalisis dari wawancara dengan pengguna dan sebagai hasil analisis dokumen. (Kendall, 2015)

\section{d. Pengenalan Crystal Reports}

Crystal Report merupakan salah satu aplikasi software yang digunakan secara khusus untuk membuat developer dalam merancang laporan. Crystal Report merupakan salah satu aplikasi perancangan laporan yang berbasis GUI ( Graphical User Interface ). Kelebihan lainnya, Crystal Report dapat terkoneksi dengan berbagai macam sumber database, hal ini meliputi: Microsoft Excel, Oracle, Access, Sql Server, My SQL, Database. Kelebihan lain dari Crystal Report adalah disediakannya banyak tools - tools bantu yang mempermudah user dalam mengembangkan sebuah sistem aplikasi yang interaktif.(Malau, 2011)

\section{e. Sistem Pakar}

dari Universitas Stanford sebagai seorang pelopor awal dari teknologi sistem pakar,mendefinisikan sistem pakar sebagai suatu program komputer cerdas yang menggunakan knowledge dan prosedur inferensi untuk menyelesaikan masalah yang cukup sulit sehingga membutuhkan seorang yang ahli untuk menyelesaikannya.Suatu sistem pakar adalah suatu sistem komputer yang menyamai kemampuan pengambilan keputusan dari seorang pakar. Suatu emulsi jauh lebih kuat dari pada suatu simulasi yang hanya membutuhkan sesuatu yang bersifat nyata dalam beberapa bidang atau hal (Listiyono, 2008)

Sistem pakar disusun oleh dua bagian yaitu lingkungan pengembangan dan lingkungan konsultasi. Lingkungan pengembangan sistem pakar digunakan untuk memasukan knowledge pakar ke dalam lingkungan sistem pakar, sedangkan lingkungan konsultasi digunakan oleh pengguna yang bukan pakar guna memperoleh knowledge pakar. Komponenkomponen yang terdapat dalam sistem pakar yaitu antar muka pengguna, basis pengetahuan (knowledge-base), akusisi pengetahuan, mesin inferensi, workplace, penjelasan, perbaikan pengetahuan.

User interface merupakan mekanisme yang digunakan oleh pengguna dan sistem pakar untuk berkomunikasi. Sistem pakar menampilkan pertanyaan-pertanyaan yang hanya perlu dijawab oleh pengguna. Pertanyaanpertanyaan itu harus dijawab dengan benar dan sesuai dengan masalah yang dihadapi pengguna. Antarmuka menerima jawaban dari pengguna dan selanjutnya sistem pakar mencari dan mencocokan ke dalam aturan sehingga diperoleh suatu kesimpulan. Jadi antarmuka menerima input berupa jawaban dari pemakai dan mengubahnya kedalam bentuk yang dapat di terima oleh sistem. Selain itu antarmuka menyajikan informasi dalam bentuk yang dapat dimengerti oleh pemakai. Menurut Mcloed (1995:1) ,Pada bagian ini terjadi dialog antar program dan pemakai, yang memungkinkan sistem pakar menerima instruksi dan input dari pemakai, juga memberikan informasi (output) kepada pemakai.

Basis pengetahuan tidak dapat dipisahkan dari mesin inferensi. Basis pengetahuan (knowledge-base) mengandung pengetahuan untuk pemahaman, formulasi, dan penyelesaian masalah. Komponen sistem pakar ini disusun atas dua elemen dasar, yaitu fakta dan aturan. Fakta merupakan informasi tentang obyek dalam area permasalahan tertentu, sedangkan aturan merupakan informasi tentang cara bagaimana memperoleh fakta baru dari fakta yang telah diketahui. Dalam studi kasus pada sistem berbasis pengetahuan terdapat beberapa karakteristik yang dibangun untuk membantu kita dalam membentuk serangkaian prinsipprinsip arsitekturnya. Prinsip tersebut meliputi : a. Pengetahuan merupakan kunci kekuatan 
INFORMATIK

Jurnal Informatika, Manajemen dan Komputer, Vol. 9 No. 1, Mei 2017

eISSN : 1979-0694

pISSN : 1979-0694

sistem pakar.

b. Pengetahuan sering tidak pasti dan tidak lengkap.

c. Pengetahuan sering miskin spesifikasi.

d. Amatir menjadi ahli secara bertahap.

e. Sistem pakar harus fleksibel.

f. Sistem pakar harus transparan.

Komponen ini mengandung mekanisme pola pikir dan penalaran yang digunakan oleh pakar dalam menyelesaikan masalah. Mesin inferensi adalah program komputer yang memberikan metodologi untuk penalaran tentang informasi yang ada dalam basis pengetahuan (knowledgebase) dan dalam workplace, dan untuk memformulasikan kesimpulan (turban : 1995 :1). Kebanyakan sistem pakar berbasis aturan menggunakan strategi inferensi yang dinamakan modus ponens. Jika terdapat aturan " IF A THEN B “, dan jika diketahui bahwa A benar maka dapat di simpulkan bahwa B juga benar.

\section{f. Forward Chaining (Runut Maju)}

Forward Chaining adalah teknik pencarian yang dimulai dengan fakta yang diketahui, kemudian mencocokkan fakta-fakta tersebut dengan bagian IF dari rules IF-THEN. Bila ada fakta yang cocok dengan bagian IF, maka rule tersebut dieksekusi. Bila sebuah rule dieksekusi, maka sebuah fakta baru (bagian THEN) ditambahkan ke dalam database. Setiap kali pencocokan, dimulai dari rule teratas. Setiap rule hanya boleh dieksekusi sekali saja. Proses pencocokan berhenti bila tidak ada lagi rule yang bisa dieksekusi. Metode pencarian yang digunakan adalah Deptth-Firstf Search(DFS), Breadth-First Search(BFS) atau Best First Searchm pendekatan dalam pelacakan dimulai dari informasi masukan dan selanjutnya mencoba menggambarkan kesimpulan, pelacakan kedepan mencari fakta yang sesuai dengan bagian IF dari aturan IF-THEN. Dengan metode forward chaining dari pendekatan dan aturan yang telah dihasilkan dapat ditinjau oleh para ahli untuk diperbaiki atau dimodifikasi untuk memperoleh hasil yang lebih baik

Forward Chaining berarti menggunakan himpunan aturan kondisi-aksi. Dalam metode ini, data digunakan untuk menentukan aturan mana yang akan dijalankan, kemudian aturan tersebut dijalankan. Mungkin proses menambahkan data ke memori kerja. Proses diulang sampai ditemukan suatu hasil. Metode inferensi runut maju cocok digunakan untuk menangani masalah pengendalian (controlling) dan peramalan (prognosis). (Verina, 2015)

\section{g. Pengertian Data}

data adalah represensasi fakta dunia nyata yang mewakili suatu objek seperti manusia (pegawai, siswa, pembeli, dan pelanggan), barang, hewan, peristiwa, konsep, keadaan dan sebagainya, yang diwujudkan dalam bentuk angka, huruf, simbol, teks, gambar, bunyi atau kombinasinya.(Fathansyah, 2012)

\section{h.Visual Basic}

adalah salah satu aplikasi pemrograman visual yang memiliki bahasa pemrograman yang sangat pepuler dan mudah untuk di pelajari. Basis bahasa pemrograman yang di gunakan dalam visual basic adalah bahasa BASIC (beginners all-purpose symbolic instruction code) yang merupakan salah satu bahasa pemrograman tingkat tinggi yang sederhana dan mudah dipelajari. Dengan visual basic,kita bias membuat program dengan aplikasi GUI (graphical user interface) atau program yang memungkinkan pengguna computer berkomunikasi dengan computer tersebuat mengunakan grafik atau gambar. (Sulistiyani, 2008)

\section{i. Sintax Fungsi Percabangan}

Fungsi percabangan adalah salah satu kunci pendukung keberhasilan dalam pemrograman.(Rusmawan, 2014)

\section{j. Pengertian MySQL}

Mysql adalah RDBMS yang cepat dan mudah digunakan, serta sudah banyak digunakan untuk berbagai kebutuhan. Mysql dikembangkan oleh MySQL AB Swedia.(Enterprise, 2011)

\section{METODOLOGI PENELITIAN}

Kerangka penelitian yang digunakan di dalam jurnal ini adalah dalam bentuk waterfall terdapat pada gambar1. 
I N F O R M A T I K A

Jurnal Informatika, Manajemen dan Komputer, Vol. 9 No. 1, Mei 2017

eISSN : 1979-0694

pISSN : 1979-0694

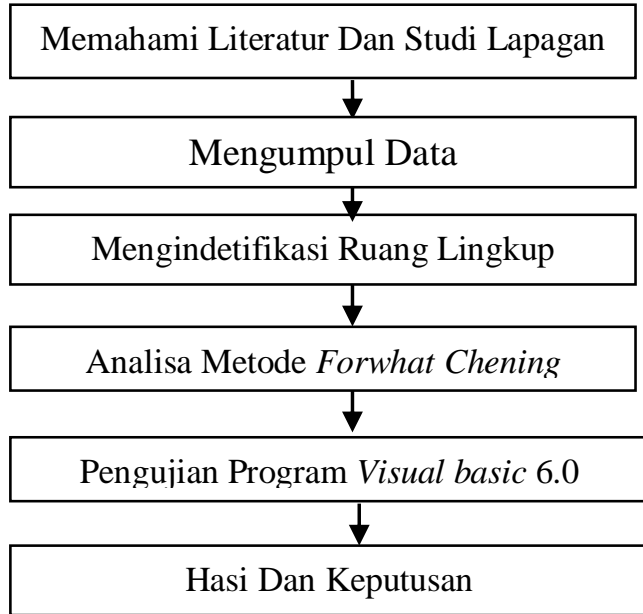

Gambar 1. Kerangka Penelitian

Adapun penjelasan kerangka penelitian di atas adalah sebagai berikut :

a. Memahami Literatur Dan Studi Lapagan

Mengumpulkan jurnal nasional maupun internasional untuk di jadikan bahan pembuatan data dan perbandingan.studi lapangan dalam penelitian ini yaitu melakukan peninjauan atau mendatagi ketempat penelitian

a. Mengumpulkan Data dilakukan dengan cara mendatagi tempat penelitian dengan cara wawan cara maupun dengan pengamatan di bengkel Chompion Motor Dumai

b. Mengindetifikasi Ruang Lingkup Masalah adapun masalah yang ada adalah minimnya pengetahun masyarakat tentang kerusakan mesin sepeda motor,belum adanya aplikasi sistem pakar di bengkel Chompion Motor dalam penggambilan keputusan berbasis apikasi

c. Analisa Metode Forwhat Chening dengan adanya metode forwhat chening dapat membatu dalam pengambilan keputusan berdasarkan rule rule yang di gunakan dalam metode tersebut sehingga dapat memberikan informasi kedalam sistim yang akan di buat

d. Pengujian Program Visual basic 6.0

salah satu aplikasi pemrograman visual yang telah di uji coba dalam megoperasikan suatu sistem pakar yang telah di implementasikan sehingga dapat memberikan informasi yang akurat dalam menyelesaikan permasalah yang telah di buat sehingga dapat menjawab semua yang di ingginkan dalam pembuatan sistem pakar diagnose kerusakan sepeda motor yamaha j 110cc.

e. Hasi Dan Keputusan dengan sistem pakar diagnosa kerusakan mesin sepeda motor yamaha dapat memberikan gambaran tentang kerusakan sepeda motor metic. penelitian tentang kerusakan motor Yamaha ini dapat mempermudah memberikan layanan dan informasi lengkap dengan metode forward chaining ini dapat memberikan suatu informasi atau suatu keputusan dalam mediagnosa kerusakan mesin sepeda motor Yamaha Mio J 110cc.

\section{HASIL DAN PEMBAHASAN}

a. Analisa kerusakan sepeda motor

Tabel 1. Jenis Kerusakan Sepeda Motor

\begin{tabular}{|c|c|}
\hline $\begin{array}{c}\text { Jenis } \\
\text { kerusakan }\end{array}$ & Gejala kerusakan \\
\hline $\begin{array}{l}\text { Kerusakan } \\
\text { piston }\end{array}$ & $\begin{array}{cc}1 & \text { Jika tenaga yang } \\
& \text { yang di hasilkan } \\
& \text { lemah } \\
2 & \text { Dan Suara kasar } \\
3 & \text { Dan Keluar asap } \\
& \text { putih dari knalpot } \\
4 & \text { DAN Kompresi } \\
& \text { turun dari standar } \\
5 & \text { Dan Oli cepat habis } \\
6 & \text { Dan Piston baret } \\
& / \text { Gores } \\
\end{array}$ \\
\hline $\begin{array}{l}\text { Kerusakan } \\
\text { pada vanbelt }\end{array}$ & $\begin{array}{ll}1 & \text { Jika Suara mesin } \\
& \text { Kasar } \\
2 & \text { Dan Akselerasi } \\
& \text { menurun } \\
3 & \text { dan Slip } \\
4 & \text { Dan Tidak bisa } \\
& \text { jalan }\end{array}$ \\
\hline $\begin{array}{l}\text { Kerusakan } \\
\text { pada Electric } \\
\text { Starter }\end{array}$ & $\begin{array}{ll}1 & \text { Jika mesin tidak bisa } \\
\text { dihidupkan } \\
\text { dengan electric } \\
\text { starter } \\
\text { Dan suara kasar } \\
\text { saat digunakan } \\
\text { dengan electric } \\
\text { starter } \\
\end{array}$ \\
\hline
\end{tabular}


IN F ORM A T I R

Jurnal Informatika, Manajemen dan Komputer, Vol. 9 No. 1, Mei 2017

eISSN : 1979-0694

pISSN : 1979-0694

\begin{tabular}{|c|c|}
\hline $\begin{array}{c}\text { Jenis } \\
\text { kerusakan }\end{array}$ & Gejala kerusakan \\
\hline & $\begin{array}{l}\text { Dan dinamo stater } \\
\text { panas }\end{array}$ \\
\hline $\begin{array}{c}\text { Kerusakan } \\
\text { pada Digital } \\
\text { CDI }\end{array}$ & 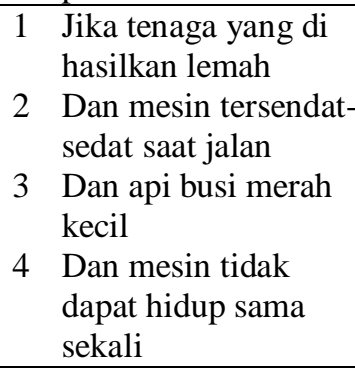 \\
\hline $\begin{array}{l}\text { Kerusakan } \\
\text { pada kelep }\end{array}$ & $\begin{array}{ll}1 & \text { Jika bahan bakar } \\
\text { boros } \\
2 & \text { Dan kompresi turun } \\
3 & \begin{array}{l}\text { Dan mesin tidak } \\
\text { stasioner }\end{array} \\
4 & \begin{array}{l}\text { Dan keluar asap } \\
\text { hitam dari kandalpot }\end{array} \\
5 & \text { Dan kelep bengkok }\end{array}$ \\
\hline $\begin{array}{l}\text { Kerusakan } \\
\text { pada rem }\end{array}$ & $\begin{array}{l}\text { 1. Jika bunyi-bunyi } \\
\text { 2. Dan daya pengerem } \\
\text { kurang } \\
\text { 3an tidak bias } \\
\text { mengerem } \\
\text { 4 Dan rem lengket }\end{array}$ \\
\hline $\begin{array}{c}\text { Kerusakan } \\
\text { pada pompa } \\
\text { oli }\end{array}$ & $\begin{array}{l}\text { 1. Jika saluran oli tidak } \\
\text { berjalan } \\
\text { 2. Mesin panas } \\
\text { berlebihan } \\
\text { 3. Oli merembet di bak } \\
\text { mesin } \\
\text { 4. Megakibatkan jim }\end{array}$ \\
\hline
\end{tabular}

Gambar 5. Jenis - jenis kerusakan sepeda motor

\section{b. Basis Pengetahuan}

Tabel 2. Relasi Gejala Sistem Pakar

\begin{tabular}{|c|l|c|}
\hline RULE & IF & THEN \\
\hline 1 & $\begin{array}{l}\text { G01,G02,G03,G04,G05, } \\
\text { G06 }\end{array}$ & K01 \\
\hline 2 & G01,G02,G07,G08,G09 & K02 \\
\hline 3 & G01, G010,G11,G12 & K03 \\
\hline 4 & G13,G14,G15,G16,G17 & K04 \\
\hline 5 & G18,G19, G20,G21 & K05 \\
\hline 6 & G22,G23,G24 & K06 \\
\hline 7 & G25,G26,G27,G28 & K07 \\
\hline
\end{tabular}

Keterangan Kerusakan Sepeda Motor:

K01 = Kerusakan pada piston

K02 = Kerusakan pada Van Belt

K03 = Kerusakan pada CDI

K04 = Kerusakan pada Klep

K05 $=$ Kerusakan pada Rem

K06 = Kerusakan pada Electric Starter

K07 = Kerusakan pada pompa oli

K08 = Tidak ditemukan

Keterangan Gejala :

G01 = Tenaga yang di Hasilkan Lemah

G02 = Suara Mesin Kasar

G03 = Keluar Asap Putih dari Knalpot

G04 = Kompresi Turun dari Standar

G05 = Oli Cepat Habis

G06 $=$ Piston Baret/Gores

G07 $=$ Akselerasi Menurun

G08 = Slip

G09 = Tidak Bisa Jalan

G010 = Mesin Tersendat Sendat Saat Jalan

G011 = Api Busi Warna Merah Kecil

G012 = Mesin Tidak Bisa Hidup Sama Sekali

G013 = Bahan Bakar Boros

G014 = Kompresi Turun

G015 = Mesin Tidak Stasioner

G016 = Keluar Asap Hitam Dari Knalpot

G017 = Klep Bengkok

G018 = Bunyi-bunyi

G019 = Daya Pengereman Berkurang

G020 = Tidak Bisa Merem Sama Sekali

G021 = Rem Lengket

G022 $=$ Mesin Tidak Bisa Dihidupkan Dengan

Electric Starter

G023 = Suara Kasar Saat Digunakan Dengan

Electric Starter

G024 = Dinamo Starter Panas

G025 = Jika Saluran Oli Tidak Berjalan

G026 $=$ Mesin Panas Berlebihan

G027 = Oli Merembet Di Bak Mesin

G028 = Mengakibatkan Jim

G029 = Gejala Tidak Diketahui

\section{c. Aturan - aturan (Rules) Forward Chaining}

Rule 1 :

IF Tenaga yang di Hasilkan Lemah

AND Suara Mesin Kasar

AND Keluar Asap Putih dari Knalpot

AND Piston Baret/Gores

AND Kompresi Turun dari Standar

AND Oli Cepat Habis

THEN Kerusakan Piston

Rule 2 :

IF Suara Mesin Kasar 
I N F O R M A T I K A

Jurnal Informatika, Manajemen dan Komputer, Vol. 9 No. 1, Mei 2017

eISSN : 1979-0694

pISSN : 1979-0694

AND Akselerasi Menurun

AND Slip

AND Tidak Bisa Jalan

THEN Kerusakan pada Van Belt

Rule 3 :

IF Tenaga yang di Hasilkan Lemah

AND Mesin Tersendat Sendat Saat Jalan

AND Api Busi Warna Merah Kecil

AND Mesin Tidak Bisa Hidup Sama Sekali

THEN Kerusakan pada Digital CDI

Rule 4 :

IF Bahan Bakar Boros

AND Kompresi Turun

AND Mesin Tidak Stasioner

AND Keluar Asap Hitam Dari Knalpot

AND Klep Bengkok

THEN Kerusakan pada Klep

Rule 5 :

IF Kendaraan Bunyi-bunyi

AND Daya Pengereman Berkurang

AND Tidak Bisa Merem Sama Sekali

AND Rem Lengket

THEN Kerusakan pada Rem

Rule 6 :

IF Mesin Tidak Bisa Dihidupkan Dengan

Electric Starter

AND Suara Kasar Saat Digunakan Dengan

Electric Starter

AND Dinamo Starter Panas

THEN Kerusakan pada Electric Starter

Rule 7 :

IF saluran oli tidak berjalan

AND Mesin panas berlebihan

AND Oli merembet ke bak mesin

AND Mengakibatkan jim

THEN Kerusakan pada pompa oli

d. Pohon Keputusan Pakar

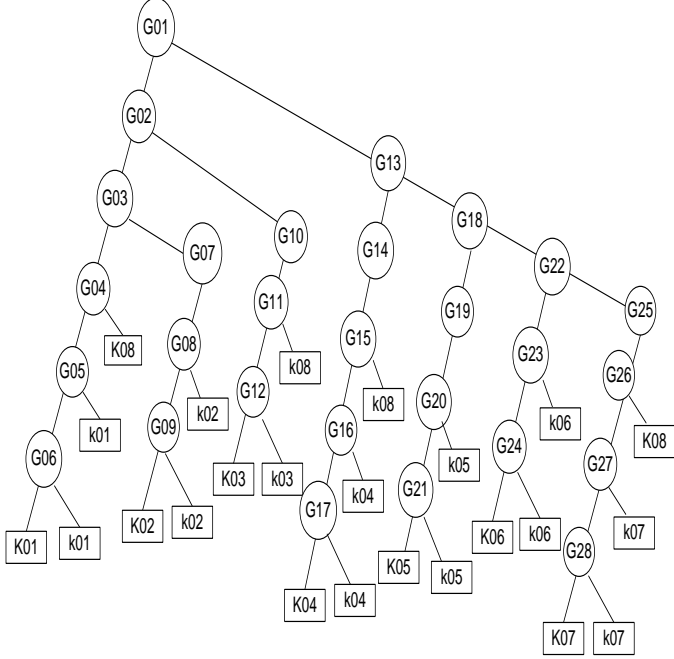

Gambar 2. Pohon Keputusan Pakar

\section{e. Layout Program}

\section{Menu utama}

Menu utama untuk mengoperasikan sub-sub menu yang berkaitan dengan tampilan interface lainya

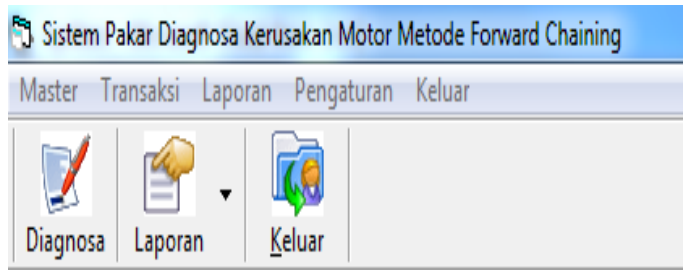

Gambar 3. Form menu utama

Menu utama untuk mengoperasikan subsub menu yang berkaitan dengan tampilan interface lainya

\section{Data pengguna}

Pada form data pengguna ini pengguna bias memasukkan data user seperti nama lengkap user name dan password sebagai akses untuk masuk ke dalam program

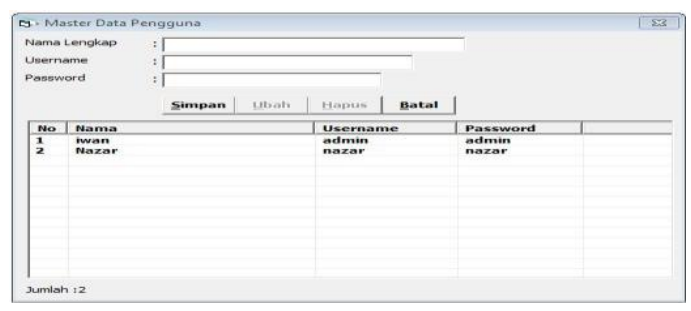

Gambar 4. Form data pengguna

\section{Data kerusakan}

Data kerusakan ini berisikan macam-macam kerusakan mesin sepeda motor Yamaha Mio J $110 \mathrm{cc}$, dengan data kerusakan ini kita bias menginputkan kode kerusakan, nama kerusakan, dan solusinya.

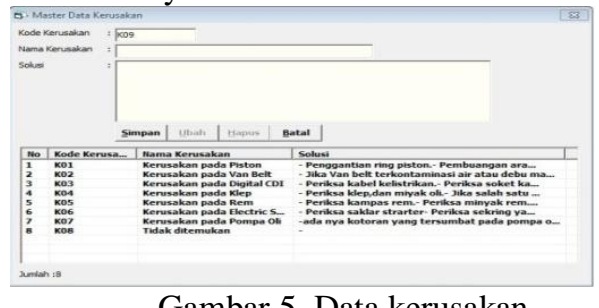

Gambar 5. Data kerusakan

\section{Data gejala}

Pada form ini digunakan untuk melakukan penginputan data kerusakan sepeda motor Yamaha Mio J 110cc dengan cara memasukan kode gejala dan nama gejala 
I N F ORM A T I K

Jurnal Informatika, Manajemen dan Komputer, Vol. 9 No. 1, Mei 2017

eISSN : 1979-0694

pISSN : 1979-0694

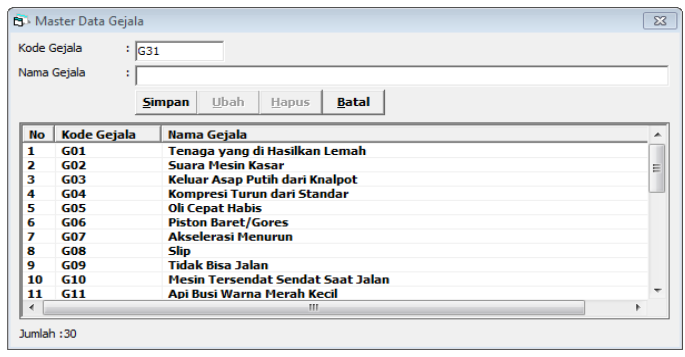

Gambar 6. Data Gejala

\section{Data rule}

Pada form rule ini digunakan untuk melakukan penginputan data yang akan di simpan dengan cara masukkan salah satu kode gejala kerusakan ke label ya dan masukan ke label tidak untuk gejala yang tidak ada di kode kerusakan, klik tombol icon pencarian untuk melihat kode gejala dan nama gejala yang telah diinput

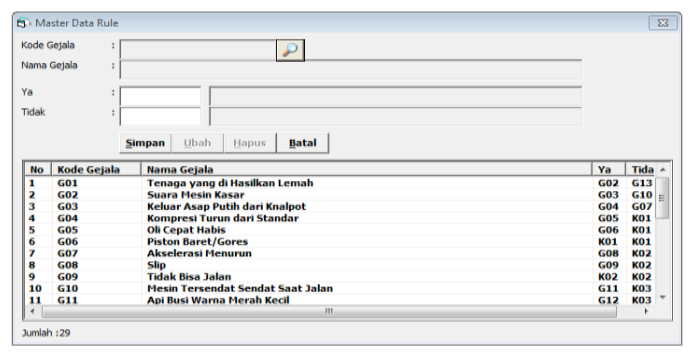

Gambar 7. Data rule

\section{Transaksi konsultasi}

Pada form ini admin dapat mengajukan pertanyaan mengenai kerusakkan sepeda motor dagan mengklik tombol mulai untuk memilih pertanyaan seputar gejala, ya atua tidak di dalam option. setelah selesai klik tombol simpan dan cetak konsultasi sehingga hasil konsultasi keluar secara otomastis.

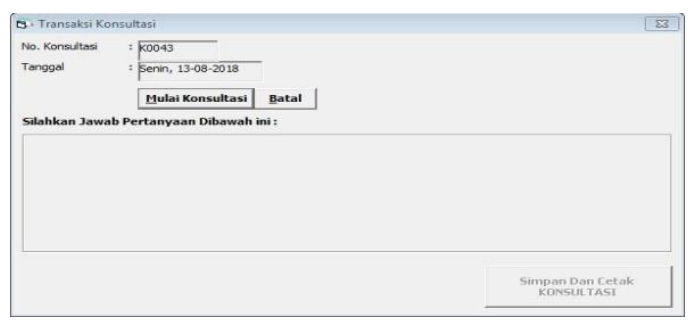

Gambar 8. Transaksi konsultasi

\section{Laporan hasil konsultasi}

Pada form ini dapat menampilkan laporan dari hasil konsultasi dengan cara klik tombol icon pencarian lalu keluar secara otomatis no transaksi dan tanggal konsultasi lalu pilih salah satu laporan yang inggin dilihat, setelah memilih salah satu laporan lalu klik tombol cetak sehingga laporan akan keluar secara otomatis.

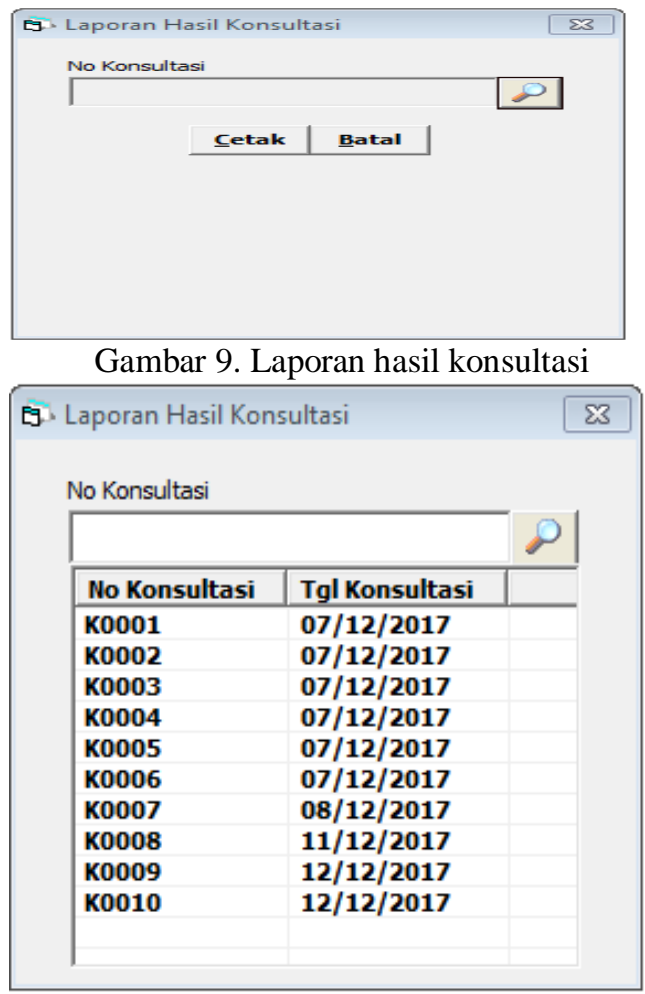

HASIL KONSULTASI

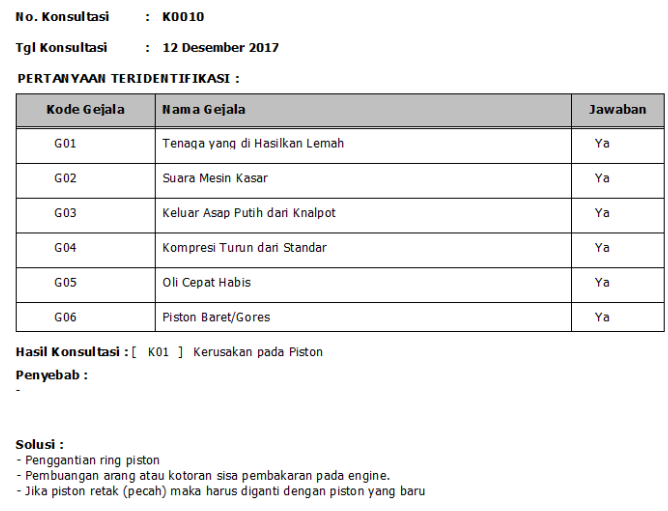

Gambar 10. Laporan hasil konsultasi

\section{KESIMPULAN}

Setelah mempelajari sejumlah permasalahan yang dihadapai dan sekaligus mencari solusi pemecahan masalah yang diajukan, maka dapat diambil beberapa kesimpulan yaitu sebagai berikut :

1. Dengan sistem pakar diagnosa kerusakan mesin sepeda motor Yamaha dapat 
I N F ORM A T I K

Jurnal Informatika, Manajemen dan Komputer, Vol. 9 No. 1, Mei 2017

elSSN : 1979-0694

pISSN : 1979-0694

memberikan gambaran tentang kerusakan sepeda motor metic.

2. Dengan ada nya penelitian tentang kerusakan motor Yamaha ini dapat mempermudah memberikan layanan dan informasi lengkap dalam perbaikan.

3. Dengan metode forward chaining ini dapat memberikan suatu informasi atau suatu keputusan dalam mediagnosa kerusakan mesin sepeda motor Yamaha Mio J 110cc.

\section{REFERENSI}

Enterprise, M. J. (2014). mysQ1.

Fathansyah, M. (2012). basis data. bandung.

Fatta, H. Al. (2007). analisa dan perancangan sistem informasi. yokyakarta.

Jogiyanto, H. (2008). analisa dan desain sistem informasi. yokyakarta.

Kendall. (2015). analisa dan perancagan sistem (2002nd ed.). PT.indeks kelompok gramedia jakarta.

Listiyono, H. (2008). Merancang dan Membuat Sistem Pakar. Jurnal Teknologi Informasi DINAMIK, XIII(2), 115-124. https://doi.org/10.1016/j.geoderma.2014.0 2.013

Malau, I. dan Y. (2011). instalasi dan konfigurasi server mysQ1. 2011.

Rusmawan, U. (2011). visual basic 6.0.

Sulistiyani, S. (2008). visual basic 6.0. yokyakarta.

Verina, W. (2015). Penerapan Metode Forward Chaining untuk Mendeteksi Penyakit THT. Jurnal Teknik Informatika Dan Sistem Informasi (Vol. 1). 